\title{
Analisis Knowledge Sharing pada Mahasiswa Program Studi Teknik Informatika STMIK GI MDP
}

\author{
Triana Elizabeth \\ Teknik Informatikan STMIK GI MDP Palembang \\ E-mail: trianaelizabeth@mdp.ac.id
}

\begin{abstract}
Abstrak
Berbagi Pengetahuan (knowledge sharing) tidak hanya dapat diterapkan pada organisasi yang berkecimpung di lingkup bisnis, namun juga dapat diterapkan pada dunia pendidikan misalnya di perguruan tinggi dan disadari atau tidak sebenarnya knowledge sharing memang telah diterapkan pada perguruan tinggi salah satunya adalah knowledge sharing antar mahasiswa. Dengan menerapkan knowledge sharing bisa jadi para mahasiswa mendapakan pengetahuan yang memang sudah ada bahkan bisa mendapatkan pengetahuan baru yang belum pernah diketahui oleh mahasiswa-mahasiswa tertentu. Penelitian ini akan membahas mengenai bagaimana penerapan knowledge sharing antar mahasiswa yang terjadi pada mahasiswa-mahasiswa program studi Teknik Informatika (TI) STMIK GI MDP. Metode yang digunakan dalam pengumpulan data pada penelitian ini adalah melalui wawancara dan melalui Focus Group Discussion (FGD) yang ditujukan terhadap mahasiswa - mahasiswa program studi Teknik Informatika STMIK GI MDP. Melalui penelitian ini dapat diketahui bahwa selama ini mahasiswa melakukan knowledge sharing melalui media elektronik dan melalui tatap muka langsung. Selain itu dapat diketahui penghalang-penghalang dalam menerapkan knowledge sharing.
\end{abstract}

Kata Kunci -Knowledge, Knowledge Sharing, Teknik Informatika, STMIK GI MDP

\begin{abstract}
Knowledge sharing is not only applicable to business in organizations but also can be applied to education, for example in college. Realized or not, knowledge sharing is already applied like knowledge sharing among students for example knowledge sharing between a students by other students or knowledge sharing between students and lecturer. By applying knowledge sharing, students can get new knowledges that is useful for their study even can make innovation. This research will discuss how the implementation of knowledge sharing among students which occurs in the course students of Teknik Informatika (TI) in STMIK GI MDP Palembang. The data collection in this research use interviews and Focus Group Discussion (FGD) with students of Teknik Informatika (TI) in STMIK GI MDP. By this research can be known that students do knowledge sharing by electronic media and by face to face. Moreover to known barriers in implementation knowledge sharing among students which occurs in the course students of Teknik Informatika (TI) in STMIK GI MDP Palembang.
\end{abstract}

Keywords-Knowledge, Knowledge Sharing, Teknik Informatika, STMIK GI MDP

\section{PENDAHULUAN}

Pengetahuan (knowledge) adalah informasi yang dimiliki oleh seorang individu yang bila dikombinasikan dengan informasi yang dimiliki oleh orang lain seperti pengalaman maka akan menjadi dasar untuk mengambil keputusan atau bertindak. Pengetahuan bukanlah sesuatu yang menjadi hak mutlak milik suatu pribadi atau suatu organisasi. Selain itu, pengetahuan 
(knowledge) adalah pemahaman tentang sesuatu hal berdasarkan interpretasi atas sebuah konteks permasalahan tertentu [1]. Pengetahuan juga didefinisikan sebagai suatu hasil pemikiran, praktik, akses informasi, dan kemampuan [2]. Pengetahuan dikategorikan menjadi dua [1], antara lain:

a. Tacit Knowledge (pengetahuan implisit)

Tacit Knowledge merupakan pengetahuan yang masih berada dalam pikiran pemiliknya. Pengetahuan implisit terdiri dari komponen kognitif dan komponen teknis. Komponen kognitif merupakan kerangka berpikir yang tidak mudah diutarakan secara terstruktur, sedangkan komponen teknis adalah konsep konkrit yang dapat diutarakan secara eksplisit atau terstruktur.

b. Explicit Knowledge (pengetahuan eksplisit)

Explicit Knowledge merupakan pengetahuan yang sudah disampaikan secara eksplisit.

Jadi, pengetahuan dapat menjadikan suatu informasi menjadi lebih berharga atau mempunyai nilai (value) sehingga dapat digunakan sebagai dasar untuk mengambil keputusan atau melakukan suatu tindakan [2].

Melihat pentingnya pengetahuan, maka pengetahuan perlu dikelola dengan baik agar dapat menghasilkan value sehingga dibutuhkan suatu manajemen pengetahuan (Knowledge Management) yang bertujuan untuk mengelola pengetahuan. Knowledge Management (KM) adalah melakukan sesuatu yang dibutuhkan untuk mendapatkan hasil maksimal dalam pengelolaan sumber daya pengetahuan [2].

KM juga diartikan sebagai upaya terstruktur dan sistematis dalam mengembangkan dan menggunakan pengetahuan yang dimiliki (knowledge reuse) untuk membantu proses pengambilan keputusan bagi peningkatan kinerja organisasi [1]. Selain itu, KM juga berperan dalam proses perubahan atau transformasi organisasi karena dapat membantu pembentukan budaya pembelajaran suatu organisasi.

Manajemen Pengetahuan atau Knowledge Management (KM) terdiri dari 4 proses utama [2], yang dapat dilihat pada Gambar 1:

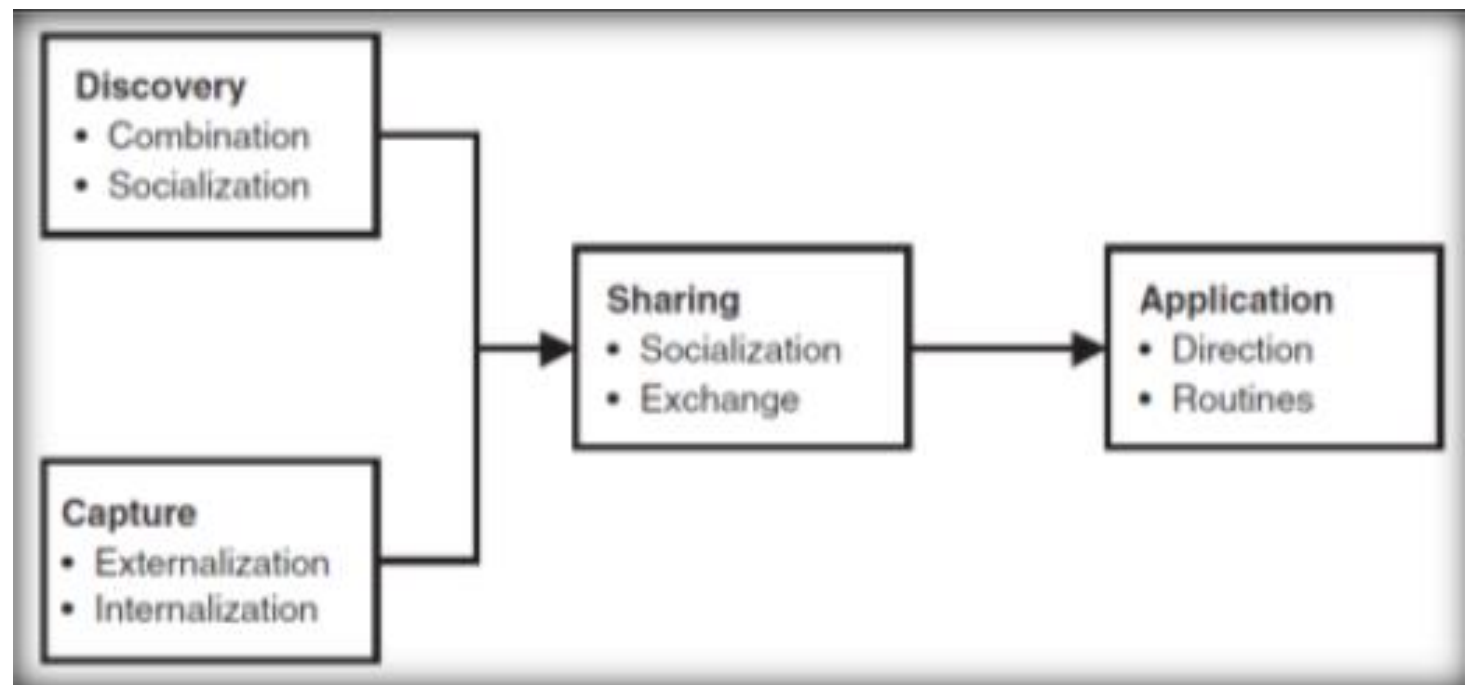

Gambar 1. Proses KM (Knowledge Management) [2]

Berdasarkan pada Gambar 1 dapat diketahui bahwa KM (Knowledge Management) merupakan serangkaian kegiatan yang melibatkan proses discovering (menemukan), capturing (menangkap), sharing (berbagi), dan applying (menerapkan) pengetahuan. 
Proses - proses tersebut didukung oleh tujuh subproses, antara lain:

a. Combination

Combination merupakan proses mensistesis pengetahuan eksplisit baru yang lebih kompleks dari pengetahuan eksplisit yang sudah ada. Hal ini dapat dilakukan melalui komunikasi, integrasi, dan sistematisasi beberapa pengetahuan eksplisit. Misalnya dengan recategorized dan recontextualized pengetahuan yang ada.

b. Socialization

Socialization merupakan proses mensintesis pengetahuan tacit dari pengetahuan tacit lainnya. Hal ini dapat dilakukan dengan melakukan kegiatan bersama.

c. Externalization,

Externalization merupakan proses mengkonversi pengetahuan tacit ke dalam bentuk pengetahuan eksplisit (kata-kata, konsep, visual, atau bahasa kiasan) sehingga lebih mudah dipahami oleh orang lain. Hal ini dapat dilakukan dengan cara metafora, analogi, dan narasi.

d. Internalization

Internalization merupakan proses mengkonversi pengetahuan eksplisit ke dalam pengetahuan tacit. Hal ini bisa juga diartikan sebagai proses pembelajaran, misalnya memperoleh pengetahuan dari sebuah buku.

e. Exchange

Exchange merupakan proses berbagi pengetahuan eksplisit. Hal ini digunakan untuk mentransfer pengetahuan eksplisit antara individu, kelompok, dan organisasi, misalnya pertukaran dokumen

f. Direction

Direction merupakan suatu proses yang dilakukan oleh individu yang memiliki pengetahuan dengan cara mengarahkan tindakan individu lain tanpa mentransfer pengetahuan yang dijadikan dasar. Misalnya dengan memberi instruksi atau keputusan.

g. Routines

Routines merupakan proses memanfaatkan pengetahuan yang tertanam di dalam prosedur, aturan, dan norma-norma yang dijadikan pedoman kerja. Hal ini dapat dilakukan juga dengan mengotomatisasi pekerjaan melalui penggunaan IT.

Dari semua proses, proses sharing (berbagi) pengetahuan merupakan salah satu yang tersulit karena banyak penghalang-penghalang seseorang melakukan sharing antara lain [3] : anggapan bahwa pengetahuan adalah kekuatan sehingga seseorang tidak mau berbagi pengetahuan yang ia miliki. Selain itu ada faktor kesibukkan dimana kesibukkan membuat seseorang tidak mempunyai waktu untuk berkumpul dengan orang lain untuk saling berbagi pengetahuan.

Berbagi pengetahuan (Knowledge Sharing) pada dasarnya merupakan tindakan menyediakan pengetahuan yang dibutuhkan oleh suatu individu ataupun suatu organisasi [2]. Berbagi pengetahuan antar individu adalah proses dimana pengetahuan yang dimiliki oleh seseorang diolah menjadi bentuk yang dapat dipahami, diserap, dan digunakan oleh individuindividu yang lain. Selain itu, berbagi pengetahuan merupakan sebuah aktivitas dimana pengetahuan ( informasi, skill, dan keahlian) ditukarkan kepada orang lain, teman, atau bahkan anggota keluarga, dan komunitas pada sebuah organisasi[3]. Knowledge sharing tidak hanya sekadar memberikan sesuatu kepada orang lain atau mendapatkan sesuatu dari mereka sebagai hasil timbal balik. Namun knowledge sharing terjadi ketika orang-orang secara alami tertarik untuk membantu sama lain untuk membangun kompetensi dan kapasitas yang baru untuk bertindak. Jadi, knowledge sharing bukan sesuatu yang dipaksakan atau disiapkan secara formal, namun mengalir secara alamiah dan ada unsur kerelaan untuk membantu orang lain demi kemajuan atau mencapai tujuan tertentu. Knowledge sharing juga disebutkan merupakan proses penciptaan pembelajaran (lesson learn)[4]. Hal itu dimaksudkan bahwa melalui kegiatanknowledge sharing, maka seseorang akan mendapatkan pemahaman, wawasan baru terhadap suatu hal, dan peningkatan tersebut merupakan salah satu bentuk dari adanya pembelajaran. 
Menurut Ismail (2009) terdapat berbagai macam factor yang mempengaruhi knowledge sharing diantaranya [9]:

a) Kepercayaan (Trust)

Sikap saling percaya memainkan peranan penting atas kelangsungan berbagi pengetahuan. Tanpa adanya kepercayaan, akan membuat seseorang enggan untuk berbagi pengetahuan. Membangun kepercayaan merupakan critical factor atas knowledge sharing.

b) Kepuasan

Ketika seorang individu merasakan kepuasan terhadap apa yang telah dilakukan, hal ini akan memotivasi dia untuk berbagi pengetahuan kepada orang lain.

c) Keyakinan Diri (Self-Efficacy)

Keyakinan diri merupakan keyakinan seseorang terhadap kemampuannya untuk mengatur dan melaksanakan tindakan-tindakan untuk mencapai tujuan yang ditetapkan, dan berusaha untuk menilai tingkatan dan kekuatan diseluruh kegiatan yang dilakukannya. Keyakinan diri sangat penting perannya dalam mempengaruhi usaha yang dilakukan, seberapa kuat usahanya, dan memprediksi keberhasilan yang akan dicapai. Keyakinan diri dapat membantu memotivasi individu untuk berbagi pengetahuan dengan orang lain. Keadaan ini pula yang meyakinkan individu bahwa dengan pengetahuan yang dimilikinya dapat menolong orang lain dan meningkatkan kinerja.

d) Kebudayaan Organisasi (Organizational Culture)

Kebudayaan organisasi merupakan nilai yang dominan yang disebarluaskan dalam organisasi sebagai nilai, norma, kepercayaan, dan best-practice yang ditanamkan pada diri setiap individu.

e) Reward dan Incentive

Sangat umum jika seseorang mengharapkan suatu reward atas apa yang telah ia kerjakan. Reward ini dapat berupa moneter maupun non moneter.

f) Infrastruktur Teknologi Informasi (Information Technology Infrastructure)

Dukungan perangkat teknologi informasi terhadap knowledge sharing sangatlah penting. Dalam era teknologi dan globalisasi saat ini, piranti teknologi informasi sangat dibutuhkan dalam melakukan komunikasi sehingga knowledge sharing dapat meningkat seperti melalui group discussion support system, network, email, chat session, online discussion, video conferencing, dan list server. Perangkat teknologi informasi yang terdiri dari peranti keras (hardware) dan peranti lunak(software) semacam ini dapat dimanfaatkan untuk meningkatkan dalam berbagi pengetahuan.

Berbagi pengetahuan (knowledge sharing) sedang banyak diminati oleh organisasi organisasi ataupun perusahaan-perusahaan karena dianggap dapat memberikan dampak positif terhadap efektivitas organisasi serta meningkatkan keunggulan kompetitif (competitive advantage). Tidak mengherankan banyak penelitian mengenai knowledge sharing bermunculan terutama pada organisasi di sektor bisnis. Sebenarnya knowledge sharing tidak hanya dapat diterapkan pada organisasi yang berkecimpung di lingkup bisnis, namun juga dapat diterapkan pada dunia pendidikan misalnya di perguruan tinggi [5]. Pada perguruan tinggi, knowledge sharing dapat dilakukan oleh dosen yang satu kepada dosen yang lain (antar dosen), antar dosen dengan mahasiswa, antar mahasiswa dengan mahasiswa yang lain, antar dosen dengan alumni, antar alumni dengan mahasiswa, bahkan terdapat sarana dimana para dosen, para mahasiswa, dan para alumni dapat saling melakukan knowledge sharing [3].

Di perguruan tinggi, knowledge sharing berperan penting karena proses belajar mahasiswa di perguruan tinggi sangat berbeda dengan proses belajar sewaktu mereka masih duduk di bangku sekolah. Sewaktu mereka masih sekolah, mereka langsung mendapatkan pengetahuan-pengetahuan dari guru yang mengajar mereka. Sedangkan, di perguruan tinggi, seorang mahasiswa diharuskan untuk mencari pengetahuan sendiri baik melalui orang lain maupun melalui studi literature dari buku-buku karena sebagai mahasiswa, mereka tidak cukup hanya mendapatkan pengetahuan dari dosennya. Dengan melakukan berbagi pengetahuan, mereka tidak hanya tahu dan memahami suatu hal namun juga dapat menerapkannya sehingga 
sewaktu mereka lulus dari bangku kuliah, mereka dapat menggunakan pengetahuan tersebut di dunia kerja dan menjadikannya sebagai kelebihan yang mereka miliki menginggat ketatnya persaingan dalam mencari pekerjaan.

Penelitian - penelitian sebelumnya yang terkait dengan penelitian ini salah satunya adalah penelitian yang dilakukan oleh Chikoore Lesley [3] yang berjudul Knowledge Sharing in Higher Education : A Study of Students Preparing Assessed Group Work. Tujuan dari penelitian tersebut adalah untuk mengetahui berbagi pengetahuan antar mahasiswa yang satu dengan mahasiswa yang lain, yang memotivasi mahasiswa untuk berbagi pengetahuan, dan implikasiimplikasi yang terjadi dengan adanya berbagi pengetahuan. Metode pengumpulan data yang digunakan oleh Chikoore Lesley adalah dengan menyebarkan kuesioner kepada 81 responden dan melakukan wawancara terhadap 12 responden yaitu para mahasiswa. Melalui penelitian yang dilakukan oleh Chikoore Lesley dapat diketahui bahwa jaringan sosial dan proses belajar mengajar secara virtual dapat digunakan untuk mendorong para siswa secara kolektif untuk berbagi dan merefleksikan apa yang telah mereka pelajari. Selain itu, para siswa perlu diberikan tugas-tugas yang menekankan mereka untuk dapat saling berbagi pengetahuan demi menyelesaikan tugas tersebut sehingga nantinya akan menumbuhkan kesadaran bagi mereka bahwa berbagi pengetahuan itu penting untuk dilakukan.

Penelitian lain sebelumnya yang terkait dengan penelitian ini adalah penelitian yang dilakukan oleh Luo Hanyang [4] yang berjudul Determinants of Knowledge Sharing in University Academic Team. Tujuan dari penelitian ini adalah untuk mengetahui faktor-faktor penentu dalam berbagi pengetahuan pada tim akademik universitas. Metode pengumpulan yang digunakan pada penelitian ini adalah menggunakan metode menyebarkan kuesioner lalu melakukan analisis data kuesioner terhadap hipotesis yang sebelumnya telah dibuat. Hasil dari penelitian ini adalah menemukan model terpadu berbagi pengetahuan pada tim akademik universitas yang mengintegrasikan Knowledge, Team Member, dan Team Climate dengan 12 hipotesis yang telah dibuat. Hasil dari penelitian ini diharapkan dapat diterapkan oleh pihak universitas untuk meningkatkan berbagi pengetahuan pada tim akademik universitas.

Dengan mengetahui pentingnya knowledge sharing pada perguruan tinggi, maka penelitian ini akan menganalisis bagaimana penerapan knowledge sharing antar mahasiswa yang terjadi pada mahasiswa-mahasiswa program studi Teknik Informatika (TI) STMIK GI MDP.

\section{METODE PENELITIAN}

Metode penelitian yang digunakan pada penelitian ini adalah metode yang banyak digunakan secara umum dimana tahap awal adalah menentukan topik penelitian dimana topik penelitian pada penelitian ini adalah mengenai knowledge sharing. Tahap selanjutnya melakukan perumusan masalah dimana hasil dari tahapan ini adalah pertanyaan penelitian / research question. Pertanyaan penelitian pada penelitian ini adalah bagaimana penerapan knowledge sharing antar mahasiswa yang terjadi pada mahasiswa-mahasiswa program studi teknik informatika STMIK GI MDP.

Setelah merumuskan masalah, tahap selanjutnya melakukan studi literatur yang sesuai dengan topik penelitian dan perumusan masalah. Langkah berikutnya adalah melakukan pengumpulan data. Salah satu metode pengumpulan data pada penelitian ini dilakukan melalui wawancara. Wawancara secara garis besar dibagi dua, yakni wawancara tak terstruktur dan wawancara terstruktur. Wawancara tidak terstruktur mirip dengan percakapan informal. Metode ini bertujuan memperoleh bentuk-bentuk tertentu informasi dari semua responden, tetapi susunan kata dan urutannya disesuaikan dengan ciri-ciri setiap responden.[7] Wawancara tak terstruktur bersifat luwes, susunan pertanyaannya dan susunan kata-kata dalam setiap pertanyaan dapat diubah pada saat wawancara, disesuaikan dengan kebutuhan dan kondisi saat wawancara, termasuk karakteristik sosial-budaya(agama, suku, gender, usia, tingkat pendidikan, pekerjaan, dsb)responden yang dihadapi.[7] 
Metode pengumpulan data pada penelitian ini dilakukan melalui wawancara tidak terstruktur terhadap mahasiswa-mahasiswa TI STMIK GI MDP untuk mengetahui bagaimana cara mereka melakukan knowledge sharing selama ini. Selain melalui wawancara, pengumpulan data pada penelitian ini juga dilakukan dengan Focus Group Discussion. Focus Group Discussion (FGD) adalah sebuah teknik pengumpulan data yang umumnya dilakukan pada penelitian kualitatif dengan tujuan menemukan makna sebuah tema menurut pemahaman sebuah kelompok, teknik ini digunakan untuk mengungkap pemaknaan dari suatu kelompok berdasarkan hasil diskusi yang terpusat pada suatu permasalahan tertentu. [8]

Berdasarkan data akademik diketahui bahwa jumlah mahasiswa program studi Teknik Informatika sampai tahun 2013 berjumlah 624 mahasiswa. Focus Group Discussion (FGD) dilakukan dengan mengumpulkan mahasiswa secara acak sebanyak 21 mahasiswa pada ruang kelas dan langsung mengajukan pertanyaan sehingga jawaban dari pertanyaan tersebut ditampung dan saling didiskusikan kembali untuk menyepakati jawaban yang tepat untuk pertanyaan tersebut.

Setelah melakukan pengumpulan data, tahap selanjutnya adalah melakukan analisa data dimana data atau informasi yang telah diperolehdari hasil pengumpulan data selanjutnya dianalisa dan diinterpretasikan sehingga data-data tersebut memberikan informasi yang bermanfaat bagi peneliti.

\section{HASIL DAN PEMBAHASAN}

Berdasarkan hasil wawancara dan Focus Group Discussion (FGD) maka dapat diketahui ada beberapa cara yang para mahasiswa Teknik Informatika lakukan untuk berbagi pengetahuan yaitu:

1. Melalui media elektronik

Pesatnya perkembangan teknologi informasi membuat para mahasiswa mau tidak mau harus mengikuti trend teknologi sehingga hal ini jugalah yang mendorong para mahasiswa berbagi pengetahuan melalui teknologi-teknologi yang sedang trend yaitu:

a. Jejaring sosial Facebook

Salah satu media yang sering digunakan adalah Facebook. Dimana melalui facebook, kita dapat membuat group dan mengundang anggota untuk bergabung di group kita. Nama facebooknya adalah Teknik Informatika STMIK MDP ( $\neg \frown)$. Anggota dari facebook ini adalah seluruh mahasiswa program studi Teknik Informatika STMIK GI MDP. Selain mahasiswa program studi Teknik Informatika, juga ada para dosen Teknik Informatika sebagai anggota. Melaui facebook ini para mahasiswa program studi Teknik Informatika dapat saling berbagi informasi misalkan informasi mengenai mata kuliah tertentu, sharing tema-tema kerja praktek dan skripsi, berbagi mengenai trend teknologi yang terbaru, dan masih banyak lagi. Berdasarkan wawancara kepada salah satu mahasiswa program studi Teknik Informatika yang sedang semester 3 mengatakan bahwa dengan adanya grup facebook ini, mereka mendapatkan banyak manfaat dimana mereka dapat mengetahui informasi-informasi mengenai mata kuliah - mata kuliah yang sedang ataupun yang akan mereka ambil dari kakak-kakak semester atas, mereka juga mendapatkan materi mata kuliah sebelum dosen memberikannya sehingga mereka dapat mempersiapkannya lebih dulu. 


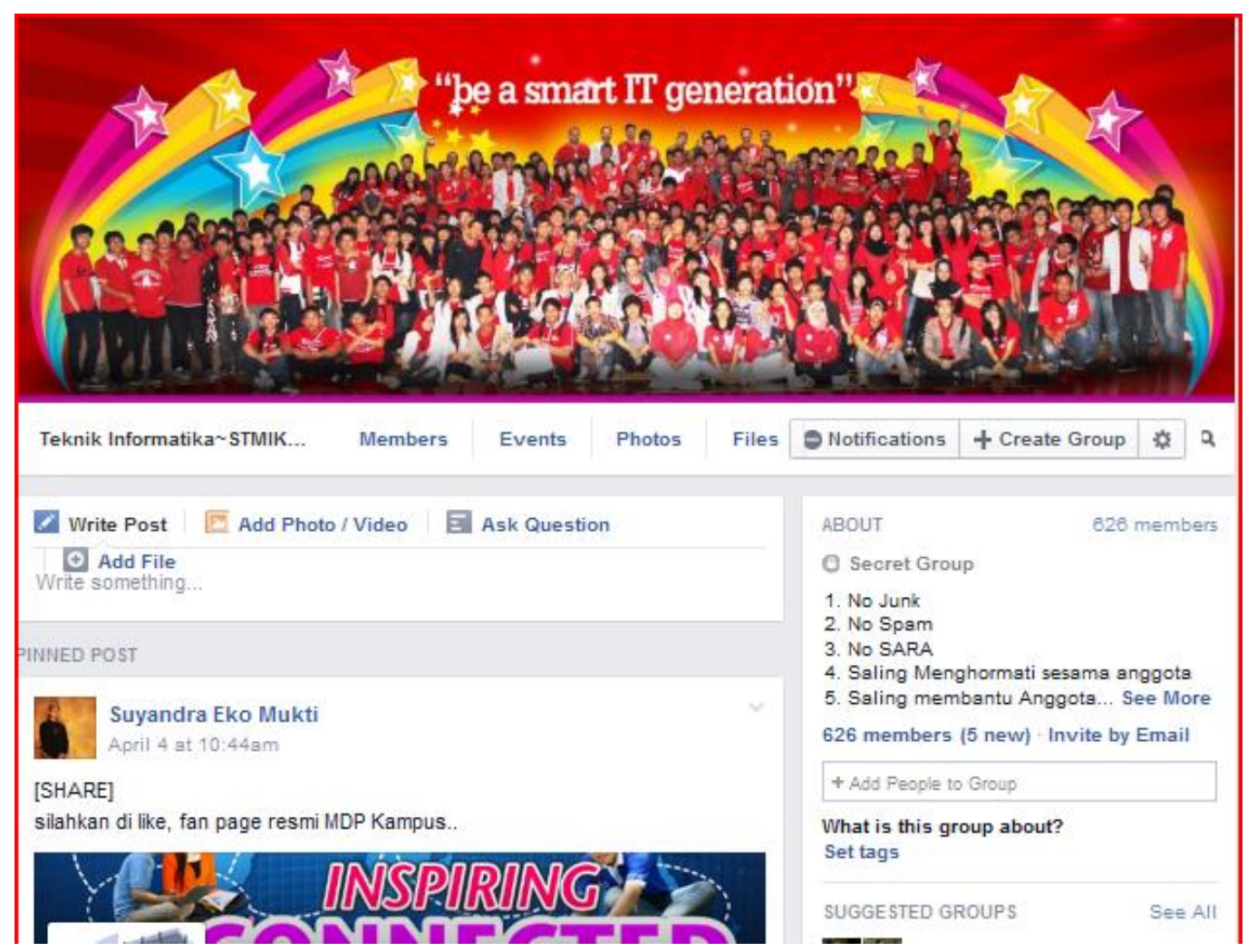

Gambar 2 Tampilan Facebook : Teknik Informatika STMIK MDP $(\frown \nabla \frown)$ [6]

b. Online Chat

Kita dapat menemukan banyak sekali aplikasi yang memungkinkan kita untuk berkomunikasi dengan orang lain bahkan terdapat aplikasi yang memungkinkan kita untuk diskusi didalam suatu group/ kelompok. Aplikasi online chat dapat diakses baik melalui desktop maupun telepon genggam (smartphone). Seperti aplikasi Line, Kakao Talk, Whats App, dan masih banyak lagi. Mereka juga menggunakan aplikasi video chat seperti Skype untuk berdiskusi mengenai tugas yang diberikan oleh dosen pada waktu liburan.

c. Forum diskusi

STMIK GI MDP menyediakan SIMPONI (Sistem Pembelajaran Online dan Interaktif) yang didalamnya terdapat forum diskusi dimana melalui sarana forum diskusi tersebut, memungkinkan dosen dan mahasiswa dapat melakukan berbagi pengetahuan yang berkaitan dengan mata kuliah yang sedang diampu. Melalui forum ini dapat memungkinkan seluruh mahasiswa pada kelas yang sama untuk melihat apa yang sedang didiskusikan sehingga akan mendorong atau memotivasi mahasiswa yang lain untuk turut berdiskusi akan suatu pokok bahasan.

2. Melalui tatap muka langsung

STMIK GI MDP menyediakan tempat bagi para mahasiswa maupun dosen untuk berkumpul dan saling sharing. Para mahasiswa prodi TI biasanya langsung menemui dosen yang diinginkan untuk menanyakan waktu yang tepat untuk diskusi kemudian mengumpulkan teman-teman yang memiliki problem yang sama untuk sama-sama berdiskusi mengenai problem tersebut dengan dosen yang bersangkutan. 
Penghalang proses berbagi pengetahuan jika melalui tatap muka langsung adalah dari segi waktu dimana dosen yang diinginkan oleh mahasiswa sebagai nara sumber sedang sibuksibuknya sehingga diskusi melalui tatap muka langsung tidak dapat dilakukan.

Selain bertatap muka langsung antara dosen dengan mahasiswa. Hal ini juga dapat dilakukan antara mahasiswa STMIK GI MDP dengan mahasiswa perguruan tinggi lainnya di Palembang. Sebagai contoh, terdapat beberapa mahasiswa program studi Teknik Informatika STMIK GI MDP yang bergabung dengan kelompok Android Palembang. Kelompok Android Palembang terdiri dari mahasiswa-mahasiswa dari berbagai perguruan tinggi yang memiliki satu kesamaan yaitu memiliki hobi untuk membuat aplikasi berbasis android. Hasil dari bergabung dengan Kelompok Android Palembang maka para mahasiswa program studi Teknik Informatika STMIK MDP memiliki inisiatif untuk membentuk kelompok android di dalam lingkungan STMIK GI MDP dengan nama MDP-Android Community. Para anggota MDP Android Community yang terdiri dari mahasiswa-mahasiswa prodi TI berkumpul setidaknya setiap minggu sekali. Mereka berbagi pengetahuan mengenai semua hal yang berkaitan dengan Android dan mencoba membuat berbagai aplikasi yang berbasis android. Hasilnya mereka dapat menggunakan aplikasi buatan mereka untuk dijadikan skripsi kelulusan. Hal ini lah yang memotivasi para mahasiswa angkatan baru untuk bergabung dengan MDP Android Community yang akhirnya MDP Android Community mendapat dukungan dari STMIK GI MDP menjadi salah satu UKM (Unit Kegiatan Mahasiswa) atau ekstrarikuler resmi dari STMIK GI MDP.

Berdasarkan wawancara, ditemukan penghalang-penghalang dalam berbagi pengetahuan antar mahasiswa, yaitu:

1. Dari segi waktu

Bisa jadi mahasiswa satu dengan mahasiwa yang lain memiliki jam kuliah yang berbeda sehingga mereka sulit untuk bertemu dimana jika yang satu punya waktu untuk berdiskusi, sedangkan yang lain sedang kuliah ataupun sedang mengerjakan tugas lain yang tidak berhubungan dengan apa yang akan didiskusikan. Penghalang ini dapat diatasi dengan membuat jadwal dan menyepakati waktu yang cocok bagi semua untuk berdiskusi seperti MDP Android Community.

2. Dari segi cara berkomunikasi

Ada beberapa mahasiswa yang sebetulnya memiliki pengetahuan lebih dari mahasiswa yang lain dan mau berbagi akan pengetahuan yang ia miliki. Namun, ia sulit mengkomunikasikannya kepada orang lain. Hal ini bisa jadi disebabkan karena memiliki sifat yang pemalu dan jarang bersosialisasi dengan orang lain. Penghalang ini dapat diatasi dengan meyakinkan orang tersebut bahwa pengetahuan yang ia miliki benar-benar dibutuhkan oleh teman-temannya, misalnya meminta orang tersebut untuk mengajari logika dalam membuat suatu aplikasi kepada teman-teman yang lain atau memberikan tugas presentasi.

3. Dari segi kemauan untuk berbagi pengetahuan

Ada mahasiswa yang disebut oleh mahasiswa lain sebagai orang yang "pelit" dimana mahasiswa tersebut mau mendapatkan pengetahuan yang dimiliki oleh orang lain namun tidak mau berbagi akan pengetahuan yang ia miliki. Hal ini dapat disebabkan karena mahasiswa tersebut takut kalau-kalau nanti jika ia berbagi pengetahuan yang ia miliki kepada teman-temannya, maka kemungkinan besar teman-temannya bisa jadi mendapatkan nilai atau IPK yang lebih besar dari dia. Memang untuk merapkan knowledge sharing harus ada kemauan tidak dengan terpaksa namun kita dapat menyakinkannya bahwa untuk dapat menerima pengetahuan, kita juga seharusnya mau membagi pengetahuan karena mungkin saja pengetahuan yang kita miliki masih kurang tepat sehingga dapat diperbaiki oleh orang lain. 


\section{KESIMPULAN}

Berdasarkan hasil dan pembahasan dapat diketahui bahwa disadari atau tidak sebenarnya knowledge sharing memang telah diterapkan pada perguruan tinggi salah satunya adalah knowledge sharing antar mahasiswa. Knowledge sharing antar mahasiswa kebanyakan dilakukan melalui sarana media elektronik seperti jejaring sosial Facebook, online chat seperti Line, Kakao Talk, Skype, dan masih banyak lagi. Dengan menerapkan knowledge sharing bisa jadi para mahasiswa mendapakan pengetahuan yang memang sudah ada bahkan bisa mendapatkan pengetahuan baru yang belum pernah diketahui oleh mahasiswa-mahasiswa tertentu. Dalam proses berbagi pengetahuan, bisa jadi muncul beberapa penghalang yaitu dari segi waktu memiliki kesibukkan yang berbeda-beda antar mahasiswa yang satu dengan mahasiswa yang lain, dari segi cara berkomunikasi adakalanya beberapa mahasiswa memiliki sifat yang pemalu atau jarang bersosialisasi dengan orang lain sehingga sulit mengkomunikasikan pengetahuan yang dimiliki kepada orang lain, dan dari segi kemauan untuk berbagi pengetahuan ada yang memang tidak mau berbagi pengetahuan yang ia miliki kepada orang lain.

\section{SARAN}

Saran kedepannya untuk mengetahui penerapan knowledge sharing dapat dilakukan dengan menggunakan metode pengumpulan data selain melalui metode wawancara, misalnya menggunakan metode pengumpulan data berupa menyebarkan kuesioner kepada para responden sehingga dapat dilakukan perbandingan metode pengumpulan data mana yang baik untuk mengetahui bagaimana penerapan knowledge sharing di bidang pendidikan. Selain itu, kedepannya diharapkan dapat mengembangkan penelitian ini dengan tidak hanya ditunjukkan pada program studi Teknik Informatika STMIK GI MDP tetapi juga ditujukan kepada program studi yang lain seperti program studi Sistem Informasi, dengan melakukan hal ini dapat diketahui mahasiswa-mahasiswa program studi mana yang paling sering melakukan knowledge sharing, baik knowledge sharing antar mahasiswa maupun knowledge sharing antar mahasiswa dan dosen.

\section{DAFTAR PUSTAKA}

[1] Kementerian Pendayagunaan Aparatur Negara dan Reformasi Birokrasi, 2011, Pedoman Pelaksanaan Program Manajemen Pengetahuan (Knowledge Management).

[2] Becerra-Fernandez, I., Sabherwal, R., 2010, Knowledge Management Systems and Process, M.E. Sharpe Inc., New York.

[3] Chikoore, L., Ragsdell, G., 2013, Knowledge Sharing in Higher Education: A Study of Students Preparing Assessed Group Work, Journal of Knowledge Management Practice, vol 14 , no 1.

[4] Hanyang, L., 2009, Determinants of Knowledge Sharing in University Academic Team, Knowledge Acquisition and Modeling (KAM 2009), vol 1, Wuhan, 30 Nov 2009 - 1 Des 2009

[5] Chen, X., 2009, The Study on Knowledge Sharing About Student Affairs Management: Comparing DUT and IIT, International Forum on Information Technology and Application (IFITA '09), vol 3, Chengdu, 15-17 Mei 2009

[6] Akun Group Facebook Teknik Informatika STMIK GI MDP, 15 November 2013, https://www.facebook.com/groups/TI.MDP/. 
Citec Journal, Vol. 1, No. 4, Agustus 2014 - Oktober 2014

[7] Mulyana, D., 2010, Metodologi Penelitian Kualitatif Paradigma Baru Ilmu Komunikasi dan Ilmu Sosial lainnya, Remaja Rosdakarya, Bandung.

[8] Bungin, B., 2007, Analisis Data penelitian Kualitatif Pemahaman Filosofis dan Metodologis ke Arah Penguasaan Model Aplikasi, Rajawali Pers, Jakarta.

[9] Ismail, W. K. W., Nor, K. M., Marjani, T., 2009, The Role of Knowledge Sharing Practice in Enhancing Project Success, Interdisciplinary Journal of Contemporary Research in Business (IJCRB), vol 1, no 7, hal 34-52. 